\title{
Exopolysaccharide (EPS) Activity test of Lactic Acid Bacteria (LAB) as Immunomodulatory
}

\author{
Kusmiati ${ }^{1}$, Kukihi $\mathrm{FE}^{2}$, Afiati $\mathrm{F}^{1}$ \\ ${ }^{1}$ Research Center for Biotechnology-Indonesian Institute of Sciences, Jl. Raya Jakarta-Bogor Km.46, Cibinong 16911 \\ ${ }^{2}$ Institut Sains dan Teknologi Nasional, Jl. Moh. Kahfi II, Jagakarsa, Jakarta Selatan 12640 \\ E-mail: kusmiatiO2@yahoo.com
}

(received 29-06-2016; revised 25-08-2016; accepted 06-09-2016)

\begin{abstract}
ABSTRAK
Kusmiati, Kukihi FE, Afiati F. 2016. Uji aktivitas eksopolisakarida bakteri asam laktat sebagai imunomodulator. JITV 21(3): 182-189. DOI: http://dx.doi.org/10.14334/jitv.v21i3.1414

Penelitian ini menguji aktivitas imunomodulator Eksopolisakarida (EPS) dari bakteri asam laktat (BAL) dan mengkarakterisasi gugus fungsinya. Strain BAL yang digunakan yaitu Lactobacillus delbrueckii subsp. bulgaricus dan Streptococcus thermophilus. EPS diekstraksi dari kedua kultur BAL tersebut. Analisis spektrum FT-IR EPS dari kedua strain BAL menunjukkan puncak serapan senyawa karbohidrat. Uji aktivitas imunomodulator dari EPS secara in vivo dihitung berdasarkan aktivitas dan kapasitas fagositosis sel makrofag cairan peritonium mencit. EPS diberikan secara oral pada mencit dengan konsentrasi $100 \mu \mathrm{g} / \mathrm{ml}, 200 \mu \mathrm{g} / \mathrm{ml}, 300 \mu \mathrm{g} / \mathrm{ml}$ selama 14 hari dan tikus diinfeksi dengan Staphylococcus aureus. Hasil menunjukkan bahwa EPS berasal dari kedua strain BAL dapat meningkatkan aktivitas dan kapasitas fagositosis sel makrofag cairan peritonium mencit. EPS dari kultur $L$. delbrueckii subsp. bulgaricus pada konsentrasi $300 \mu \mathrm{g} / \mathrm{ml}$ menunjukkan aktifitas fagositosis sel makrofag dan EPS dari kultur S. thermophilus konsentrasi $300 \mu \mathrm{g} / \mathrm{ml}$ menunjukkan kapasitas fagositosis tertinggi. Kesimpulan uji potensi EPS sebagai imunomodulator berasal dari kultur L. delbrueckii subsp. bulgaricus dan S. thermophilus menunjukkan bahwa EPS dari kedua strain tersebut mampu meningkatkan aktifitas dan fagositas sel makrofag peritonium mencit.
\end{abstract}

Kata Kunci: Eksopolisakarida, Bakteri Asam Laktat (BAL), Imunomodulator, Yoghurt, Fourier Transform-Infra Red (FT-IR)

\begin{abstract}
Kusmiati, Kukihi FE, Afiati F. 2016. Exopolysaccharide (EPS) activity test of lactic acid bacteria (LAB) as immunomodulatory. JITV 21(3): 182-189. DOI: http://dx.doi.org/10.14334/jitv.v21i3.1414

Immunomodulatory activity assay and characterization of exopolysaccharide (EPS) from Lactic Acid Bacteria (LAB) was done in Bogor. Bacteria used in this study was LAB strains of Lactobacillus delbrueckii subsp. bulgaricus and Streptococcus thermophilus. Exopolysaccharide was extracted from L. delbrueckii subsp. bulgaricus and S. thermophilus then characterized with FT-IR spectrophotometer to determine the functional group. IR spectrum analysis using Fourier Transform-Infra Red (FTIR) showed that EPS from both LAB isolates were carbohydrate compounds. Immunomodulatory activity in vivo from EPS was measured using phagocytic activity and phagocytic capacity macrophage cells from mice peritoneal cavity fluid. Exopolysaccharide were given orally to mice in concentrations of $100 \mu \mathrm{g} / \mathrm{ml}, 200 \mu \mathrm{g} / \mathrm{ml}$ and $300 \mu \mathrm{g} / \mathrm{ml}$ for 14 days then the mice were infected with Staphylococcus aureus. Result showed that EPS from both LAB isolate enhanced either phagocytic activity and phagocytic capacity macrophage cell from mice peritoneal fluid. EPS from $L$. delbrueckii subsp. bulgaricus concentration $300 \mu \mathrm{g} / \mathrm{ml}$ showed the highest phagocytic activity of macrophage cells and EPS from S. thermophilus concentration $300 \mu \mathrm{g} / \mathrm{ml}$ showed the highest phagocytic capacity. It is concluded that EPS potency tested as immunomodulatory derived from a culture of $L$. delbrueckii and $S$. thermophilus subsp.bulgaricus are able to increase the activity and phagocytosis murine peritoneal macrophages.
\end{abstract}

Key Words: Exopolysaccharide, Lactic Acid Bacteria (LAB), Immunomodulatory, Yoghurt, Fourier Transform-Infra Red (FT-IR)

\section{INTRODUCTION}

Immuno system balance disorder is the one causing such an inflammation, infection and autoimmune diseases. One of prevention attempts of the disorder is restoring the immune system balance through providing immunomodulatory. Immunomodulatory is a compound that may change immune response by preventing/normalizing an abnormal immune reaction (Suhirman \& Winarti 2007).

Yogurt is a healthy drink especially in the gastrointestinal tract containing lactic acid bacteria (LAB) of Lactobacillus delbrueckii subsp. bulgaricus and Streptococcus thermophilus (Mazahreh \& Ershidat 2009). Many studies showed that LAB in yogurt has potential has therapy effect including as the 
immunostimulatory (Weerathilake et al. 2014; Patel et al. 2012).

Exopolysaccharide (EPS) is a sugar residue secreted by microbes to its surrounding. EPS is secreted by LAB in the form of mucus (De Vuyst \& Degees 1999). Several lactic acid bacteria produce EPS playing role as nature texture producer in yogurt, cheese and milkbased foods manufacturing (Harutoshi 2013). EPS also has profitable biological characteristics as immunostimulator, antitumor, antiulcer and cholesterolreducer (Welman \& Maddox 2003). EPS is beneficial in food, health and cosmetic industry and need further studies. Potential of the EPS as immunomodulatory study is excessively studied.

EPS compound isolated from Sarcodon aspratus mushroom is able to intensify macrophage cells activity in producing cytokines and intensifying its phagocytosis (Im 2010). Biological activities of EPS depend on composition and its monomer bond, so it is crucial to characterize EPS generated both chemically and biologically (Madhuri \& Prabhakar 2014).

One of methods may be used to characterize functional group of a compound is by spectrophotometry Fourier Transform Infra Red (FTIR) (Sunil et al. 2013). This study was aimed to measure the potential of EPS compound resulted from L. delbrueckii subsp. bulgaricus and S. thermophiles isolated from yogurt as immunomodulatory and determine functional group in the EPS compound.

\section{MATERIALS AND METHODS}

\section{Preparation and characterization of exopolysaccharide (EPS)}

\section{Preparation of Lactic Acid Bacteria (LAB)}

Bacteria used in this study were $L$. delbrueckii subsp.bulgaricus and $S$. thermophiles which are the collection of Indonesian Culture Collection (InaCC) Indonesian Institute of Sciences. One ose each from culture stock was transferred into compact de Mann Rogossa Sharpe (MRS, Merck) media and incubated for 48 hours at $37^{\circ} \mathrm{C}$.

\section{Observation of the LAB morphology}

Preparate swabs and Gram staining were conducted for the fresh $L$. delbrueckii subsp.bulgaricus and $S$. thermophilus which then were observed under Leica microscope with 1000x magnification.

\section{Inoculation of the LAB into the pre-culture}

One ose LAB from regeneration media was collected aseptically and then inoculated into $20 \mathrm{~mL}$ pre-culture media and incubated in shaker incubator at $37^{\circ} \mathrm{C}$ for 48 hours.

\section{Production of exopolysaccharide on fermentation media}

As much as 2\% LAB culture from pre-culture media were inoculated into $250 \mathrm{~mL}$ liquid MRS aseptically. Then it was incubated in the shaker incubator at $37^{\circ} \mathrm{C}$ for 72 hours.

\section{Exopolysaccharide extraction}

Exopolysaccharide was extracted from 72 hours old $\mathrm{LAB}$ culture and boiled at $100^{\circ} \mathrm{C}$ for 15 minutes (Feldman et al. (2013). The boiling was aimed to inactivate enzyme degrading the EPS. The culture was chilled into room temperature, and then centrifuged in $6000 \mathrm{rpm}$ for 10 minutes. Tricloroacetate $85 \%$ was added then chilled at $4^{\circ} \mathrm{C}$ and centrifuged in $6000 \mathrm{rpm}$ for 10 minutes in $4^{\circ} \mathrm{C}$. Supernatant was accommodated and added by cold ethanol $96 \%$ by ratio $1: 3$ and idled for 48 hours at $4^{\circ} \mathrm{C}$. That fusion then was centrifuged in $6000 \mathrm{rpm}$ for 10 minutes at $4^{\circ} \mathrm{C}$. The sediment EPS was washed by hot water twice. Biomass from the extraction was dried in the vacuum oven at $50^{\circ} \mathrm{C}$. It then was weighed as dry weight of crude EPS (mg).

\section{Total sugar analysis of EPS samples using Phenol Sulfate method}

Phenol Sulfate method with the glucose as a standard was applied to measure the EPS content (Chaplin 1986). The EPS was hydrolyzed into monomer D-glucose. Carbohydrate and phenol in the strong acidic environment, followed by heating process, experienced dehydration producing furfural and furfural methyl hydroxy which condensed with the phenol turned into yellow-orange. The absorbability of the color was measured using spectrophotometer UV-Vis in the wavelength by $490 \mathrm{~nm}$.

\section{Protein analysis of EPS samples using Lowry method}

Protein level was measured by Lowry method using Bovine Serum Albumin (BSA) (Copeland 1994). In the divalent ion copper alkali formed complex with peptide bond which then was reduced into monovalent ion. Monovalent copper ion and radical group of tyrosine, tryptophan and cysteine reacted with foline solvent producing unstable compound which reduced into blue tungsten molybdenum. That color absorption was measured by light spectrophotometer showed on maximum wave length by $750 \mathrm{~nm}$. 
Characterization of exopolysaccharide using Spectrophotometry Fourier Transform Infra Red (FTIR)

Exopolysaccharide of LAB was characterized using spectrophotometer FT-IR (Shimazu) to determine its functional group. One part of EPS extract was mixed with 99 parts of dry Kalium bromide $(\mathrm{KBr})$ then compressed into $3 \mathrm{~mm}$ diameter slab. The slab then was analyzed in infrared spectrum in frequency range by 400-4,000 $\mathrm{cm}^{-1}$ (Sunil et al. 2013).

\section{Measurement of In Vivo phagocytosis activities and capacity of macrophage}

Macrophage activity and capacity were observed under a 10x100 magnificent light microscope (Won et al. 2011; Yim et al. 2005). Animal experimental was performed in the Laboratory of Veterinary of Bogor Agricultural University-Dramaga, Bogor. The experimental animal used was male mice (Mus musculus) strain DDY, in 6-8 weeks old, with 18-21 g of body weight. The mice were acclimated for 7 days ahead. The mice was divided into 9 experimental groups: (1) normal control, (2) positive control, (3) negative control, (4) EPS L. delbrueckii subsp. bulgaricus (LB) $100 \mu \mathrm{g} / \mathrm{ml}$, (5) EPS L. delbrueckii subsp.bulgaricus (LB) $200 \mu \mathrm{g} / \mathrm{ml}, \quad$ (6) EPS $L$. delbrueckii subsp. bulgaricus (LB) $300 \mu \mathrm{g} / \mathrm{ml}$, (7) EPS S. thermophilus (ST) $100 \mu \mathrm{g} / \mathrm{ml}, \quad$ (8) EPS $S$. thermophilus (ST) $200 \mu \mathrm{g} / \mathrm{ml}$ and (9) EPS $S$. thermophilus (ST) $300 \mu \mathrm{g} / \mathrm{ml}$. The positive control used standard $\beta$-glycan (Takeda) $200 \mu \mathrm{g} / \mathrm{ml}$. There were 3 mice in each experimental group.

The experiment was conducted for 14 days, where in the $15^{\text {th }}$ day, those experimental animals were injected by intraperitoneal suspension of Staphylococcus aureus $\left(1 \quad \mathrm{x} \quad 10^{6} \mathrm{cfu} / \mathrm{ml}\right)$. Those experimental animals were euthanatized 1 hour after infection and then their peritoneal liquid were collected. Swab preparation was made for all samples and then fixated using methanol for 5 minutes, stained with Giemsa and left for 20 minutes and then washed using distilled water.

\section{Phagocytosis activity}

Phagocytosis activity value is the number of macrophage cells that actively phagocyte Staphylococcus aureus in 100 macrophage cells. Phagocytosis activity was presented in percent, with the formulation (Ranjith et al. 2008) as the following:

$$
\% \text { Activity }=\frac{\begin{array}{c}
\text { The number of } \\
\text { active macrophage }
\end{array}}{\begin{array}{c}
\text { The number of } \\
\text { whole macrophage }
\end{array}} \quad \times 100 \%
$$

\section{Phagocytosis Capacity}

Phagocytosis capacity value is the number of bacteria ingested by 50 active macrophages (Ranjith et al. 2008). This parameter was observed by staining with Giemsa and then the bacteria number was counted under microscope. Phagocytosis is a devouring process on bacteria or strange objects by enfolding those things using macrophage cytoplasm.

\section{Data Analysis}

Determining of immunomodulatory activity of crude EPS from L. delbrueckii subsp. bulgaricus (LB) and S. thermophilus (ST) was through macrophage activity and capacity induced by Staphylococcus aureus bacteria by in vivo. Data were analyzed by one way ANOVA with 3 replications using SPSS ver 22.0 with $\mathrm{P}=0.05$. This analysis was then followed by Duncan Multiple Range Test.

\section{RESULTS AND DISCUSSION}

\section{Exopolysaccharide (EPS) Characterization}

\section{Morphology of Lactic Acid Bacteria (LAB)}

The morphology of LAB isolate grew in the regeneration media was observed using Gram staining (Figure 1). It shows that L. delbrueckii subsp. bulgaricus and $S$. thermophilus isolates are Gram positive bacteria. L. delbrueckii isolate formed rod shape, meanwhile, the $S$. thermophilus isolate formed cocus chain shape.

\section{Sugar and protein content of the exopolysaccharide (EPS)}

Bacteria isolate was fermented in the liquid MRS, that is a selective media for LAB growth. Fermentation temperature was kept at $37^{\circ} \mathrm{C}$, which is the optimum temperature for LAB growth. In the 72 hours fermentation, bacteria growth reached stationer phase, where in this phase, the culture was being collected due to secunder accumulation of EPS.

Table 1 shows that LAB isolate produced more EPS (65.40 mg per $\mathrm{L})$ than the LAB LB isolate $(61.40 \mathrm{mg}$ er L). This is in accordance with a study conducted by Cerning (1995) that reported LAB ST produced EPS by $50-350 \mathrm{mg} / \mathrm{L}$, meanwhile the LAB LB produced $60-250$ $\mathrm{mg} / \mathrm{L}$. EPS amount produced is influenced by composition of media such as concentration of carbon and nitrogen or growth condition of bacteria such as the temperature, $\mathrm{pH}$, incubation time and genetic factor. Different LAB species tends to have different 
preference to certain carbon resource. Effect of using of different carbohydrate was observed by Mataragas et al. (2004), where showed that glucose could not increase total biomass production of Leuconostoc mesenteroides and Lactobacillus curvatus. On the other hand, Liew et al. (2005) reported that there was an effect of glucose on the amount of biomass of Lactobacillus rhamnosus cel.

EPS amount is also influenced by extraction method applied. Heating stage in the begining of the extraction $\left(100^{\circ} \mathrm{C}\right)$ may increase EPS recovery, so that increase EPS amount produced. This is allegedly that enzimes afford to degrade EPS have been inactivated. The addition of trichloroacetate $85 \%$ to precipitate protein causes the decrease of EPS amount produced, as a result of EPS precipitation led by the trichloroacetate (Rimada \& Abraham 2003).

The LAB LB in this study had more glucose than LAB ST isolate. It was resulted by use of more glucose as carbon resource in the LAB LB compared to the LAB ST. Weigher dry weight of EPS within lower glucose in the LAB ST than in the LAB LB was allegedly due to contamination of other compound.

The EPS produced by LAB LB contained lower protein than the LAB ST synced with the high glucose content resulted. Lower protein content shows purer EPS. As well known that protein and salt are contaminant (Yadav et al. 2011).

\section{Analysis of EPS extracted from L. delbrueckii subsp. bulgaricus and $S$. thermophilus cultures with Fourier Transform Infra Red (FTIR).}

Fourier Transform Infra Red (FT-IR) was used to determine functional group of the compounds within the EPS. As it shows in the Figure 2 and 3, both isolate had similar infra red IR and typical uptake of polysaccharides showed by its wave number. Table 2 shows that EPS produced by both isolates, each had hydroxyl $(-\mathrm{OH})$, methyl and methylene $(-\mathrm{CH})$, carbon ($\mathrm{C}=\mathrm{O})$ in the carboxylate and $\mathrm{C}-\mathrm{C}$ vibration. This shows that the EPS produced is carbohydrate compound.
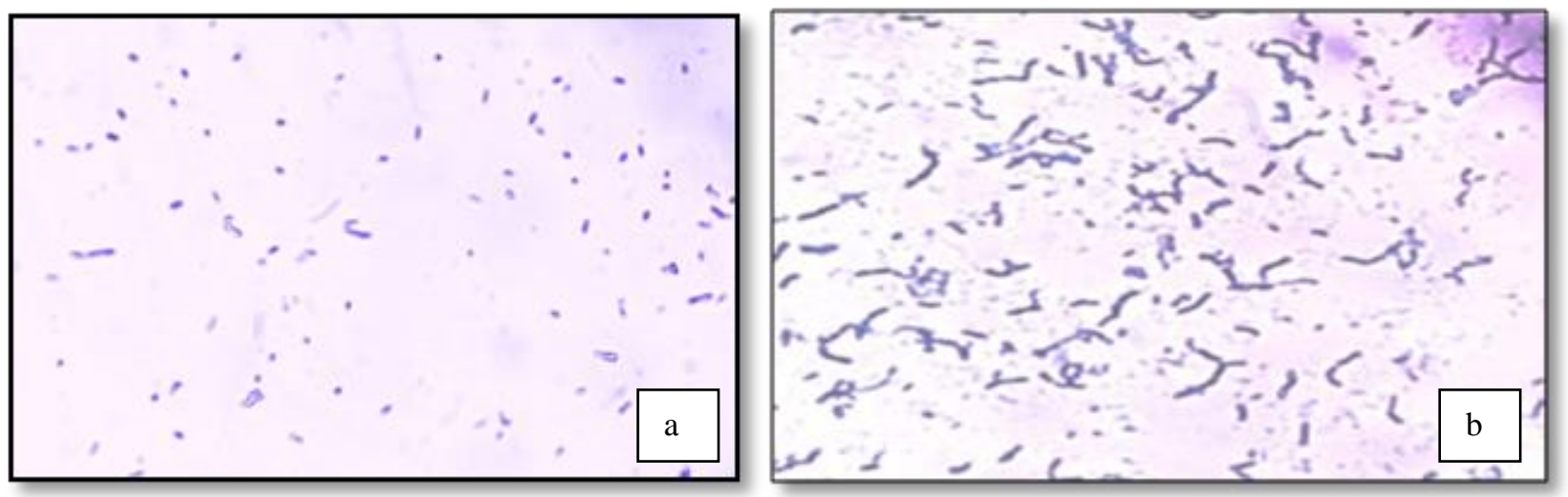

Figure 1. Morphology of $L$. delbrueckii subsp. Bulgaricus magnificaton by $10 \times 100$.

(a) and S. thermophilus (b) under microscope with the

Table 1. Dry weight of crude EPS, sugar and protein of EPS from L. delbrueckii subsp. bulgaricus and S. thermophilus

\begin{tabular}{|c|c|c|c|}
\hline Bacteria & $\begin{array}{l}\text { DW of crude EPS } \\
(\mathrm{mg} / 250 \mathrm{ml} \text { media })\end{array}$ & $\begin{array}{l}\text { Level of EPS equivalent } \\
\text { to Glucose }(\%)\end{array}$ & Protein Level (\%) \\
\hline $\begin{array}{l}\text { L. delbrueckii } \quad \text { subsp. } \\
\text { Bulgaricus }(\text { BAL LB) }\end{array}$ & $15,35 \pm 0,29$ & $49,96 \pm 0,25$ & $1,20 \pm 0,03$ \\
\hline S. thermophiles (BAL ST) & $16,35 \pm 0,32$ & $24,17 \pm 0,06$ & $7,19 \pm 0,12$ \\
\hline
\end{tabular}




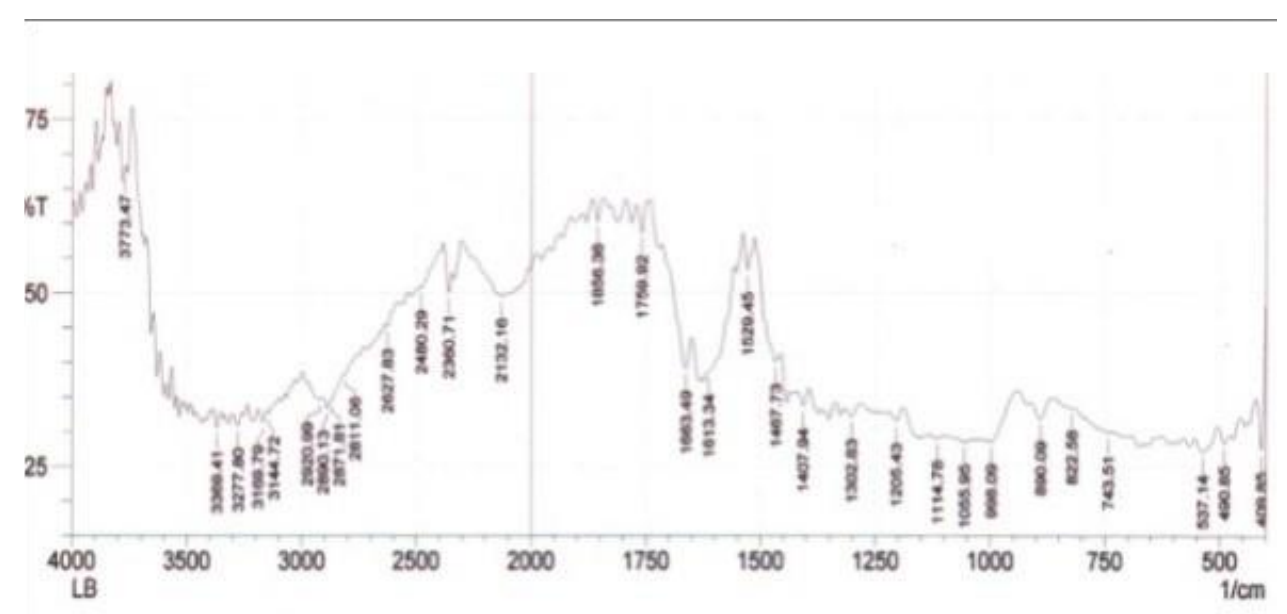

Figure 2. FTIR Spectrum of EPS L. delbrueckii subsp. bulgaricus

\section{円SHIMADZU}

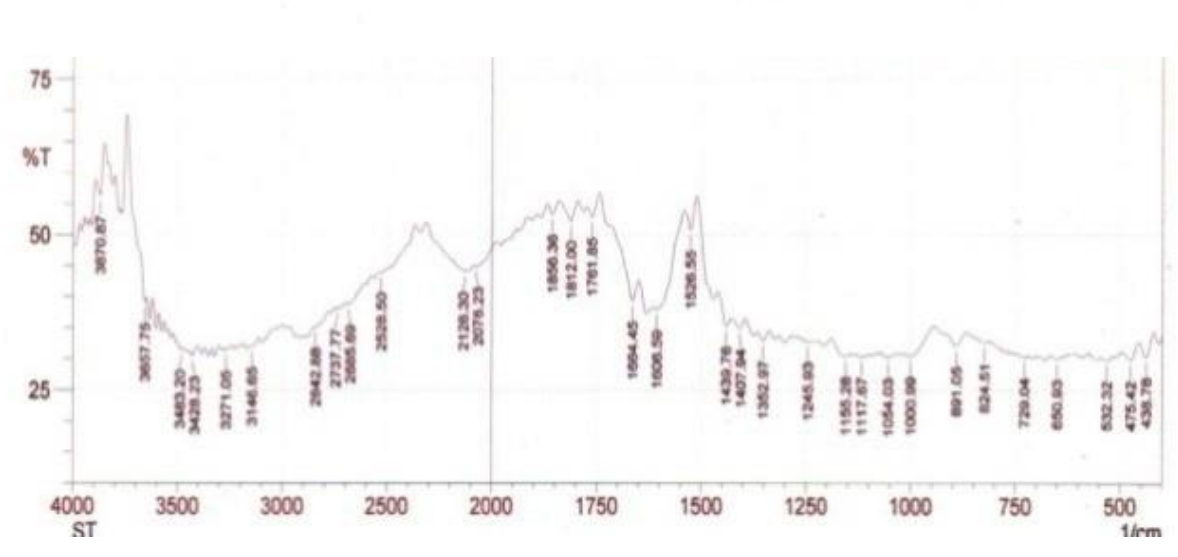

Figure 3. FTIR Spectrum of EPS S. thermophilus

Table 2. Spectrum interception result Fourier Transform Infra Red (IR) exopolysaccharide

\begin{tabular}{lcc}
\hline \hline Bacteria & Wave Number $\left(\mathrm{cm}^{-1}\right)$ & Functional Groups \\
\hline & $3,144-3,369$ & $-\mathrm{OH}$ band \\
& $2,811-2,920$ & $\mathrm{C}-\mathrm{H}\left(\mathrm{CH}_{2}, \mathrm{CH}_{3}\right)$ band \\
L. delbrueckii subsp. & $1,613-1,663$ & $-\mathrm{C}=\mathrm{O}$ band \\
bulgaricus & 1,407 & $-\mathrm{C}=\mathrm{O}$ vibration \\
& 1,055 & C-C dan C-O vibration \\
\hline & $3,146-3,483$ & $-\mathrm{OH}$ band \\
& 2,842 & Stretching $-\mathrm{CH}$ band \\
S. thermophilus & $2,076-2,126$ & alkuna group \\
& 1,664 & $-\mathrm{C}=\mathrm{O}$ band \\
1,606 & Stretching enol and amida \\
1,054 & C-C and C-O Vibration \\
\hline
\end{tabular}




\section{EPS Immunodulatory assay}

Activity of EPS of LAB as immunomodulatory was measured based on its capability on increasing activity and capacity of phagocytosis of macrophage cells in the peritoneum liquid of mice under a microscope (Figure 1). Data were analyzed using one way ANOVA followed by Duncan Test.

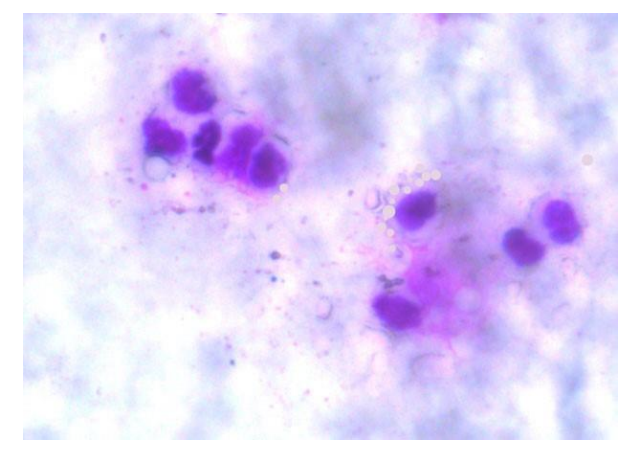

Figure 4. Macrophage cell actively phagocytes $S$. aureus bacteria

Phagocytosis activity measurement using macrophage cells collected from peritoneum liquid of 9 mice groups was presented in the Table 3. The normal control had the lowest phagocytosis activity by $10.33 \%$ than all experimental groups. The negative control had phagocytosis activity score by $43.67 \%$, which higher than the normal control. This shows that infection of the Staphylococcus aureus bacteria may lead macrophage cell as an immune system response. The positive control had the highest phagocytosis activity by $74.67 \%$. EPS from LB of $300 \mu \mathrm{g} / \mathrm{ml}$ had the highest phagocytosis activity by $61 \%$ than the other. It may be concluded that EPS compound extracted from LAB LB and ST cultures has immunomodulator activity by increasing macrophage activity in the mice peritoneum. This is in line with LeBlanc et al. (2002) who said that several strains of LAB are able to increase immune response of mediator by $\mathrm{T}$-lymphocyte proliferation, increasing phagocytosis capacity of mononuclear cell and increasing antitumor $\mathrm{NK}$ cell activity (natural killer). The LAB may increase immunomodulatory function through macrophage and lymphocyte cell activity (Kirjavainen et al. 1999). Immunomodulatory activity becomes mediator of interaction between immune cell and whole LAB cell or the cells components such as peptidoglycan, tamaroic acid and exopolysaccharide (Amrouche et al. 2006).

Phagocytosis capacity assay was performed by randomly selecting 50 macrophage cells containing minimal 3 Staphylococcus aureus from active macrophage cells. Table 3 shows the normal control group had lowest phagocytosis capacity by 35.33 cells bacteria per 50 active macrophage cells. Positive control group had the highest phagocytosis capacity among all the experimental groups by 574.67 cells bacteria per 50 active macrophages. Experimental group provided EPS from LAB ST $300 \mu \mathrm{g} / \mathrm{ml}$ had the highest macrophage capacity by 556.67 cells bacteria per 50 active macrophage cells among the experimental groups.

Test results show that oral providing of EPS isolate LB and ST for 14 days was able to increase phagocytosis activity and capacity of peritoneum macrophage cells. This proves that EPS is a compound that may influence immune system response.

Mechanism of EPS compound in increasing phagocytosis activity and capacity of macrophage is not well known. Several studies reported that EPS

Table 3. Phagocytosis activity of macrophage cell (per 100 cells) and phagocytosis capacity (the number of bacteria devoured per 50 active macrophage cells)

\begin{tabular}{lcc}
\hline \hline Test Group & Phagocytosis Activity $\%)$ & Phagocytosis Capacity $(\%)$ \\
\hline Normal & $10,33 \pm 2,08^{\mathrm{a}}$ & $35,33 \pm 3,06^{\mathrm{a}}$ \\
Negative & $43,67 \pm 0,58^{\mathrm{b}}$ & $177,33 \pm 5,13^{\mathrm{b}}$ \\
Positive & $74,67 \pm 1,15^{\mathrm{h}}$ & $574,67 \pm 4,16^{\mathrm{i}}$ \\
EPS LB $100 \mu \mathrm{g} / \mathrm{ml}$ & $53,33 \pm 1,53^{\mathrm{d}}$ & $239 \pm 3,61^{\mathrm{c}}$ \\
EPS LB $200 \mu \mathrm{g} / \mathrm{ml}$ & $56,33 \pm 1,53^{\mathrm{e}}$ & $341,33 \pm 8,14^{\mathrm{e}}$ \\
EPS LB $300 \mu \mathrm{g} / \mathrm{ml}$ & $61 \pm 1,00^{\mathrm{g}}$ & $540 \pm 2,65^{\mathrm{g}}$ \\
EPS ST $100 \mu \mathrm{g} / \mathrm{ml}$ & $47 \pm 1,73^{\mathrm{c}}$ & $266,67 \pm 11,50^{\mathrm{d}}$ \\
EPS ST $200 \mu \mathrm{g} / \mathrm{ml}$ & $53,33 \pm 1,53^{\mathrm{d}}$ & $489 \pm 6^{\mathrm{f}}$ \\
EPS ST $300 \mu \mathrm{g} / \mathrm{ml}$ & $59 \pm 1,00^{\mathrm{f}}$ & $556,67 \pm 6,03^{\mathrm{h}}$
\end{tabular}

Different letter in the same column means significant different $(\mathrm{P}<0.05)$. 
may be recognized by one of many C-type lectin receptor (CLRs) involved in intercepting antigen by macrophage cells (Abbas et al. 2015). CLRs receptor is located in phagocyte plasma membrane. EPS will be bind with a receptor changing the receptor of signal cells inducing several cellular responses including cell proliferation, differentiation, migration of immune cells and phagocytosis.

\section{CONCLUSION}

EPS is substantial extracellular bioactive molecule playing a role in biologic and therapeutic activities. Results showed that EPS from strains $L$. delbrueckii subsp. bulgaricus and S. thermophiles cultures is able to increase phagocytosis activity and capacity of macrophage cells of mice's peritoneum. S. thermophiles produced higher dry EPS extract than the L. delbrueckii subsp. bulgaricus. EPS produced by those both bacteria generated typical spectra infra red from polysaccharide. EPS from L. delbrueckii subsp. bulgaricus $300 \mu \mathrm{g} / \mathrm{ml}$ showed the highest macrophage activity, while the EPS from $S$. thermophilus $300 \mu \mathrm{g} / \mathrm{ml}$ showed the highest macrophage capacity. Those results scientifically provide preliminary information that LAB may be used as active ingredient for medicine or supplement for human being.

\section{REFERENCES}

Abbas A, Litchman A, Pillai S. 2015. Cellular and molecular immunology. 8th ed. London (UK): Wiley.

Amrouche T, Boutin Y, Prioult G, Fliss I. 2006. Effects of bifidobacterial cytoplasm, cell wall and exopolysaccharide on mouse lymphocyte proliferation and cytokine production. Int Dairy J. 16:70-80.

Cerning J. 1995. Production of exopolysaccharides by lactic acid bacteria and dairy propionibacteria. Le Lait. 75:463-475.

Chaplin MF. 1986. Monosaccharides,p.2. In: Carbohydrate analysis, a practical approach. Chaplin MF, Kennedy JF, editors. Oxford (UK): IRL Press.

Copeland RA. 1994. Methods for protein analysis. Wilmington: The dupont pharmaceutical company. p. 39-57.

De Vuyst L, Degeest B. 1999. Heteropolysaccharides from lactic acid bacteria. FEMS Microbiol Rev. 23:153-177.

Feldman J, Semjonovs P, Civrovica I. 2013. Potential of exopolysaccharides in yoghurt production. Int $\mathrm{J}$ Biol Food Vet Agric Eng. 7:424-427.

Harutoshi T. 2013. Exopolysaccharides of lactic acid bacteria for food and colon health applications. Croatia: INTECH Open Access Pub.
Im S. 2010. Activation of macrophages by exopolysaccharide produced by mk1 bacterial strain isolated from Neungee mushroom, sarcodon aspratus. Immune Network. 1:230238 .

Kirjavainen PV, El-Nezami HS, Salminen SJ, Ahokas JT, Wright PF. 1999. The effect of orally administered viable probiotic and dairy lactobacilli on mouse lymphocyte proliferation. FEMS Immunol Med Microbiol. 26:131-135.

LeBlanc JG, Matar C, Valdez JC, LeBlanc J, Perdigon G. 2002. Immunomodulating effects of peptidic fractions issued from milk fermented with Lactobacillus helveticus. J Dairy Sci. 85:2733-2742.

Liew SL, Ariff AB, Raha AR, Ho YW. 2005. Optimization of medium composition for the production of a probiotic microorganism, Lactobacillus rhamnosus, using response surface methodology. Int J Food Microbiol. 102:137-142.

Madhuri K, Prabhakar K. 2014. Microbial exopolysaccharides: Biosynthesis and potential applications. Orient J Chem. 30:895-904.

Mataragas M, Drosinos EH, Tsakalidou E, Metaxopoulos J. 2004. Influence of nutrients on growth and bacteriocin production by Leuconostoc mesenteroides L124 and Lactobacillus curvatus L442. Antonie van Leeuwenhoek 85:191-198.

Mazahreh A, Ershidat O. 2009. The Benefits of lactic acid bacteria in yogurt on the gastrointestinal function and health. Pak J Nutr. 8:1404-1410.

Patel S, Majumder A, Goyal A. 2012. Potentials of exopolysaccharides from lactic acid bacteria. Indian $\mathbf{J}$ Microbiol. 52:3-12.

Ranjith MS, Ranjitsingh AJA, Shankar SG, Vijayalaksmi GS, Deepa K, Harcharan SS. 2008. Enhanced phagocytosis and antibody production by Tinospora cordifolia - A new dimension in immunomodulation. Afr J Biotechnol. 7:81-85.

Rimada P, Abraham A. 2003. Comparative study of different methodologies to determine the exopolysaccharide produced by kefir grains in milk and whey. Le Lait. 83:79-87.

Suhirman S, Winarti C. 2007. Prospek dan fungsi tanaman obat sebagai imunomodulator. Balitan Obat dan Aromatik. Bogor (Indones): Balai Besar Penelitian dan Pengembangan Pascapanen Pertanian.

Sunil TP, Amarsinh AB, Trishala BGA, Tejswini RN. 2013. Isolation, screening and optimization of exopolysaccharide producing bacterium from saline soil. J Microbiol Biotechnol Res. 3:24-31.

Weerathilake WADV, Rasika DMD, Ruwanmali JKU, Munasinghe MADD. 2014. The evolution, processing, varieties and health benefits of yogurt. Int J Sci Res Pub. 4:1-10. 
Kusmiati et al. Exopolysaccharide (EPS) activity test of lactic acid bacteria (LAB) as immunomodulatory

Welman AD, Maddox IS. 2003. Fermantation performance of an exopolysaccharide-producing strain of Lactobacillus delbruckii subsp.bulgaricus. J Ind Microbiol Biotechnol. 30:661-668.

Won DP, Lee JS, Kwon D. 2011. Immunostimulating activity by polysaccharides isolated from fruiting body of Inonotus obliquus. Molecul Cells. 31:165-173.

Yadav V, Prappulla SG, Jha A, Poonia A. 2011. A novel exopolysaccharide from probiotic Lactobacillus fermentum CFR 2195: Production, purification and characterization. J Biotechnol Bioinf Bioeng. 1:415421.

Yim JH, Son E, Pyo S, Lee HK. 2005. Novel sulfated polysaccharide derived from red-tide microalga Gyrodinium impudicum strain KG03 with immunostimulating activity in vivo. Marine Biotechol. 7:331-338. 